\title{
Tingkat Ketergantungan (Usability) E-learning di Fakultas Saitek UIN Walisongo Semarang
}

\author{
Adzhal Arwani Mahfudh11, Favian Agung Rizki², Ahilla Salma Alfaza ${ }^{3}$ \\ 123Universitas Islam Negeri Walisongo Semarang \\ Adzhal@walisongo.ac.id favianagung@gmail.com alfazaahillasalma@gmail.com
}

\begin{abstract}
Utilizing technology, especially the internet to support the teaching and learning process, is what happened in the 21st century. E-learning is one of the learning innovations in the network that allows users to access material or collect assignments online. The benefits of elearning are so numerous and can help lectures, users can access anywhere without being limited by space and time. The method used is descriptive research, which in its implementation consists of data collection, analysis and interpretation of the meaning of the data obtained. . This study aims to determine the level of usability or usability that exists on the e-leraning website of UIN WALISONGO Saintek Faculty, whether the system has been made that meets the usability criteria or not, in terms of Learnability, Efficiency, Memorability, Errors, and Satisfaction. After conducting research, the authors obtain data that e-learning meets usability criteria seen from the data in the field that is the result of the survey. So, Walisongo e-learning can be used as a support for learning effectively and efficiently.
\end{abstract}

Keyword : E-learning, Technology, Usability, and Website.

\begin{abstract}
Abstrak
Memanfaatkan teknologi khususnya internet demi menunjang proses belajar mengajar, adalah yang terjadi pada masa abad 21 ini. E-learning merupakan salah satu inovasi pembelajaran dalam jaringan yang memungkinkan penggunanya dapat mengakses materi ataupun mengumpulkan tugas secara online. Manfaat e-learning yang begitu banyak dan dapat membatu perkuliahan, pengguna dapat mengakses dimanapun tanpa dibatasi ruang dan waktu. Metode yang digunakan yaitu penelitian deskriptif, dimana dalam pelaksanaanya terdiri dari pengumpulan data, analisis dan interpretasi arti dari data yang diperoleh. . Penelitian ini bertujuan untuk mengetahui seberapa tingkat ketergunaan atau usability yang ada pada website e-leraning UIN WALISONGO Fakultas Saintek, apakah sistem yang telah dibuat itu sudah memenuhi kriteria usability atau belum, ditinjau dari sisi Learnability, Efficiency, Memorability, Errors, dan Satisfaction. Setelah dilakukan penelitian, penulis memperoleh data bahwa e-learning memenuhi kriteria usability dilihat dari data di lapangan yaitu hasil survey. Jadi, e-learning Walisongo dapat digunakan sebagai penunjang pembelajaran secara efektif dan efisien.
\end{abstract}

Kata Kunci: E-learning, Teknologi, Usability, dan Website. 


\section{PENDAHULUAN}

Era globalisasi identik dengan istilah modernisasi, seluruh aspek kehidupan, mulai dari keluarga hingga ke masyarakat umum, termasuk pada bidang Pendidikan, semuanya pasti menunjukkan perubahan, mengikuti perkembangan dan kemajuan teknologi yang tergolong begitu pesat. Teknologi memiliki peranan penting dalam setiap perkembangan tak terkecuali dalam bidang Pendidikan, Pendidikan adalah upaya memajukan atau mengembangkan budi pekerti, pikiran maupun jasmani untuk mencapai taraf hidup atau kemajuan yang lebih baik, para pendidik harus memperhatikan dan memahami apa yang dibutuhkan para murid demi menumbuhkan perubahan-perubahan yang di inginkan (Desriyanti, 2017).

Pendidikan

mempunyai peranan penting dalam kemajuan bangsa dan negara, baik negara maju maupun negara berkembang. Kemajuan bangsa dapat dilihat dari hasil Pendidikan yang di terapkan bangsa itu sehingga menghasilkan SDM yang berkualitas (Rahadian, Rahayu and Oktavia, 2019). Pendidikan khususnya di UIN WALISONGO SEMARANG memanfaatkan teknologi khususnya internet demi menunjang proses belajar mengajar, salah satu media pembelajaran berbasis web yang dibuat adalah website e-learning . Elearning merupakan salah satu inovasi pembelajaran dalam jaringan yang memungkinkan penggunanya dapat mengakses materi ataupun mengumpulkan tugas secara online (Pambudi, 2018).

Hampir seluruh universitas di Indonesia juga menggunakan media pembelajaran ini, karena manfaatnya yang begitu banyak dan dapat membatu perkuliahan, pengguna dapat mengakses dimapanapun tanpa dibatasi ruang dan waktu, apalagi di masa pandemic ini, yang diharuskan kita untuk bekerja dan belajar dari rumah, ini sangat di manfaatkan univeristas. Para pengajar dapat memberikan materi dari rumah begitu juga mahasiswa yang diberi pelajaran dapat mengakses dan mempelajarinya dari rumah. Sudah banyak universitas yang menerapkan pembelajaran daring dan menggunakan media e-learning ini sebagai media pembelajaran, namun dalam penggunaan e-learning masih banyak ditemukan kendala, kendala yang ditemukan seperti sering terjadinya salahnya persepsi pengguna terhadap e-learning yang ad, sehingga bukan lagi efektivitas dan efisiensi yang diperoleh, akan tetapi justru menyebabkan pembelajaran daring yang dilakukan tidak efisien dan efektif, pengguna yang mengalami kesulitan menggunakan e-learning tersebut dikarenakan kurang familiar dengan $e$ learning, karena mungkin sebelum pandemic ini berlangsung, paracivitas akademikbelum maksimal dalam penggunaan $e$ - learning ini, elearning dirasa terlalu rumit sehingga sulit dipelajari, e- learning tidak sesuai dengan kebutuhan pengguna dan belum mengakomodasi kebutuhan yang penting bagi pengguna. Hal tersebut terjadi karena programmer yang membuat web tersebut kurang memperhatikan faktor interaksi manusia dan komputer. Ada beberapa penyebab interaksi manusia dengan komputer menjadi kurang baik, salah satunya ada keterbatasan kemampuan para pengguna untuk mengoperasikan 


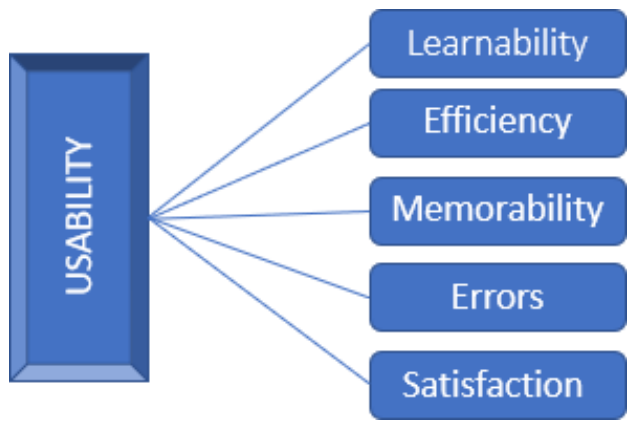

Sumber diagram : (Pambudi, 2018)

sistem yang belum dikenal atau dirasa baru, dan programmer pembuat web itupun harus memahami psikologi dari pengguna sehingga interaksi manusia dan computer terbangun dengan baik (Pambudi, 2018).

Dalam interaksi manusia dan computer, kita kenal dengan yang namanya usability . Usability pada dasarnya adalah efektif, efisien, aman pada penggunaannya, mudah untuk dipelajari/dipahami, diingat, serta memiliki utilitas yang baik. website $e$ learning sendiri harusnya sudah menerapkan prinsip usability agar pengguna bisa lebih merasakan manfaatnya, dan menjadi salah satu faktor penentu keberhasilan sistem tersebut. Menurut Nielsen (1994)

, usability memiliki lima komponen yaitu : Learnability (Mudah difahami), Efficiency (Efisien), Memorability (Kemudahan dalam mengingat), Errors (Pencegahan kesalahan), dan Satisfaction (Kepuasan pengguna) (ABDUL MUFTI, 2015).

1. Learnability : Seberapa mudah bagi pengguna memahami saat pertama kali melihat.

2. Efficiency : Seberapa cepat dapat menyelesaikan perintah (input).

3. Memorability : Saat pengguna menggunakan lagi seberapa ingat (terbisa) terhadap penggunaanya.

4. Errors : Berapa banyak kesalahan yang diperbuat saat menggunakannya.

5. Satisfaction : Seberapa nyaman pengguna dengan antarmuka tersebut

\section{METODE}

Dalam penelitian ini menggunakan metode penelitian deskriptif, dimana dalam pelaksanaanya terdiri dari pengumpulan data, analisis dan interpretasi arti dari data yang diperoleh. Pengumpulan data merupakan salah satu aspek penting dalam penelitian ini karena perannya dalam kelancaran dan keberhasilan dalam suatu penelitian. Metode pengumpulan kuesioner adalah teknik pengumpulan data melalui formulirformulir yang berisi pertanyaanpertanyaan yang diajukan secara tertulis pada seseorang atau sekumpulan orang untuk mendapatkan jawaban atau tanggapan dan informasi yang diperlukan oleh peneliti (Pambudi, 2018).

Populasi berkaitan dengan seluruh kelompok orang, peristiwa, atau benda yang menjadi pusat perhatian penelitian untuk diteliti. Sampel merupakan suatu bagian dari populasi. Hal ini mencakup sejumlah anggota yang dipilih dari populasi. Jumlah responden yang dilibatkan dalam penelitian ini adalah sebanyak sebanyak 50 mahasiswa yang berasal dari berbagai prodi yang ada di Fakultas Saintek UIN Walisongo Semarang, terdiri dari prodi Teknologi Informasi, Matematika, Pendidikan matematika, Fisika, Pendidikan Fisika, Kimia dan Pendidikan Kimia (Asnawi, 2018).

Penelitian ini menggunakan metode pengumpulan data yaitu Angket atau Kuesioner yang disebar melalui online menggunakan google form. Bentuk pertanyaan adalah pilihan ganda (multiple choice questions) Skala pengukuran variabel 
dalam penelitian ini mengacu pada Skala Likert (Likert Scale), dimana masing-masing dibuat dengan menggunakan skala $1 \quad-5$ kategori jawaban, yang masing-masing jawaban diberi score (nilai) atau bobot yaitu banyaknya score antara 1

sampai 5, dengan rincian sebagai berikut :

1. Jawaban SB (Sangat Baik) diberi nilai 5

2. Jawaban B (Baik) diberi nilai 4

3. Jawaban $\mathrm{C}$ (Cukup) diberi nilai 3

4. Jawaban TB (Tidak Baik) diberi nilai 2

5. Jawaban STB (Sangat Tidak Baik) diberi nilai 1

(Pambudi, 2018).

Penelitian ini bertujuan untuk mengetahui seberapa tingkat ketergunaan atau usability yang ada pada website e-leraning UIN WALISONGO Fakultas Saintek, apakah sistem yang telah dibuat itu sudah memenuhi kriteria usability atau belum, ditinjau dari sisi Learnability, Efficiency , Memorability, Errors, dan Satisfaction.

\section{KERANGKA TEORI}

Ada beberapa difinisi para ahli mengenai usability antara lain :

Menurut Nielsen, usability ukuran kualitas pengalaman pengguna pada saat menggunakan sistem itu, baik yang berupa aplikasi perangkat lunak ataupun lainya, sehingga pengguna dapat mengoperasikanya dengan mudah (Alif Muwafiq Baihaqy dkk, 2016).

Menurut Sastramihardja, usability adalah proses optimasi interaksi antara pengguna dengan sistem yang dapat dilakukan dengan interaktif, sehingga pengguna mendapatkan informasi yang tepat atau menyelesaikan suatu aktivitas

pada aplikasi tersebut dengan lebih baik (Asnawi, 2018).

Menurut ISO, International Organization for Standardization , definisi dari usability adalah (924111): "sejauh mana produk dapat digunakan oleh pengguna tertentu untuk mencapai tujuan yang ditentukan dengan efektifitas, efisiensi, dan kepuasan dalam konteks yang ditentukan untuk digunakan (Mareta Siregar, 2019).

Menurut Joseph Dumas dan Janice Redish usability mengacu kepada bagaimana pengguna bisa mempelajari dan menggunakan produk untuk memperoleh tujuannya dan seberapa puaskah mereka terhadap penggunaannya (Asnawi, 2018).

Nielsen juga membuat parameter untuk mengukur nilai usability suatu sistem. Menurut dia parameter tersebut harus terpenuhi semua demi terciptanya sistem yang sempurna. yaitu Easy to learn yang artinya pengguna dapat dengan mudah menjalankan aplikasi atau sistem tersebut, memudahkan pengguna dalam penggunaan navigasi, dan mencari informasi. Efficient to use yang artinya ketika pengguna sudah menyesuaikan diri atau mempelajari sistem tersebut, pengguna bisa mencari informasi yang dicarinya dengan cepat sehingga produktivitasnya dapat meningkat. Easy to remember yang artinya setelah penguna tidak lagi menggunakan sitem tersebut dalam jangka waktu yang cukup lama, pengguna tidak kesulitan lagi untuk mengingat dan menyesuaikan diri

dengan sistem itu. Few Errors yang artinya dapat meminimalisir pengguna dalam melakukan kesalahan pada saat mengoperasikan sistem tersebut, 
apabila melakukan error atau kesalah ketika menggunakan sistem tersebut, pengguna bisa memperbaiki dengan mudah dan tidak menyebabkan kesalahan yang fatal, Pleasant to use yang artinya pengguna bisa puas , tidak mengalami kekecewaan pada saat menggunakan sitem yang dibuat, sehingga pengguna dapat menjadikan sistem tersebut sebagai prioritas pada saat dia membutuhkan atau saat mengerjakan sesuatu yang perlu dibantu oleh sistem yang semacam itu (Wulandari, 2018).

E-learning bisa dikatakan komponen fleksibel learning yang menggambarkan rangkaian aplikasi dan proses yang menggunakan media elektronik apapun, isi e-learning dapat berupa pembelajaran berbasis komputer, berbasis web, ruang kelas maya. E-learning dapat memudahkan kita pada saat ingin mencari informasi atau belajar tanpa dibatasi ruang dan waktu. Konsep e-learning mencangkup 3 hal utama yaitu konten, komunikasi, dan teknologi (Indhira, 2015).

\section{PEMBAHASAN}

Penelitian dilakukan dengan cara mengumpulkan data hasil survey lapangan, yaitu menyebar angket pertanyaan melalui google form. Instrumen pertanyaan yang diajukan, menekankan pada point Learnability (kemudahan pengguna dalam memahami), Efficiency (kecepatan dalam menyelesaikan perintah), Memorability (tingkat terbiasa atau seberapa ingat terhadap penggunaan), Errors (kesalahan yang diperbuat saat menggunakan), dan Satisfaction (kenyamanan pengguna). Instrumen Pertanyaan yang digunakan yaitu:

1. Seberapa mudah bagi pengguna memahami saat pertama kali melihat dan menggunakan $E$ learning Walisongo?

2. Seberapa cepat pengguna dapat
menyelesaikan tugasnya
menggunakan sistem E-learning
Walisongo ?

3. Seberapa ingat (terbiasa) terhadap penggunaan E-learning Walisongo kembali setelah lama tidak menggunakan?

4. Seberapa banyak kesalahan yang diperbuat saat menggunakan $E$ learning Walisongo ? (Jika menurut anda tidak ada atau tidak melakukan kesalahan saat menggunakan, pilih opsi sangat baik dan begitu pun sebaliknya).

5. Seberapa puas anda dengan sistem pembelajaran

Walisongo ?.

Angket pertanyaan disertai dengan jawaban opsi, ada lima pilihan yang disediakan oleh penulis yaitu sangat baik, baik, cukup, kurang, dan sangat kurang. Responden hanya dapat memilih satu pilihan diantara lima opsi. Semua instrumen pertanyaan wajib diisi dengan satu pilihan opsi oleh responden, setelah itu tanggapan dapat direkam dan

terkirim secara otomatis ke dalam link tanggapan penulis. Angket pertanyaan disebar secara acak kepada beberapa Mahasiswa Fakultas Saintek UIN Walisongo Semarang yang pernah menggunakan website e-learning, http://elearning.walisongo.ac.id/.

Setelah data didapatkan, kemudian diolah dan dianalisis.

E-learning merupakan suatu sistem yang memanfaatkan teknologi informasi dalam proses pembelajaran. E-learning juga dapat diartikan sebagai pembelajaran yang disusun menggunakan sistem elektronik atau komputer sehingga mampu mendukung proses

pembelajaran. jadi, dengan adanya Elearning proses pembelajaran dapat dilaksanakan tanpa harus bertatap muka secara langsung antara pendidik 
dan peserta didik. E- learning juga dapat didefinisikan sebagai bentuk suatu teknologi informasi yang diterapkan pada bidang pendidikan berupa website yang dapat diakses kapan saja dan dimana saja (Thoyyibah T., 2018).Universitas Islam Negeri Walisongo Semarang juga mempunyai website e-learning dengan alamat http://elearning.walisongo.ac.id/.

Website e-learning walisongo adalah sistem yang dibuat sebagai media pembelajaran mahasiswa UIN Walisongo Semarang secara virtual, yang diharapkan dapat memudahkan mahasiswa dalam proses pembelajaran tanpa dibatasi ruang dan waktu. Berikut adalah tampilan website Elearning UIN Walisongo Semarang

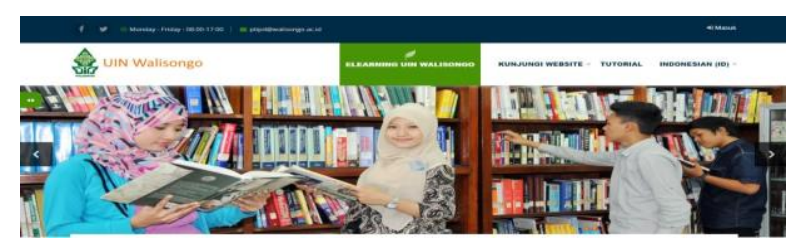

Gambar 1. Tampilan Website E-learning UIN Walisongo Semarang.

Berikut adalah diagram data jurusan mahasiswa atau responden :

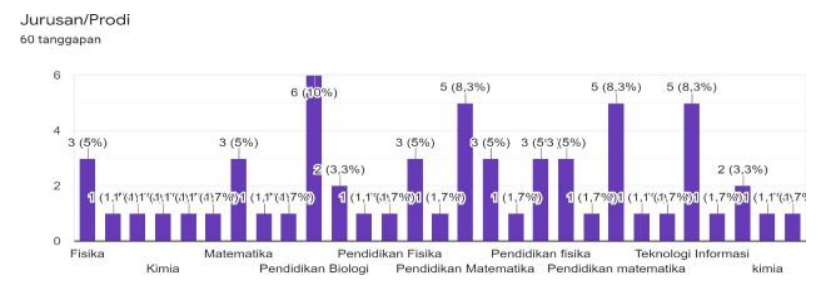

Grafik 1. Statistik Jumlah Mahasiswa Berdasarkan Jurusan.

Dari hasil survei yang sudah dilakukan, penulis memperoleh 60 responden yang berasal dari beberapa jurusan di Fakultas Saintek UIN Walisongo Semarang. Diperoleh data bahwa 60 responden, berasal dari 13 mahasiswa jurusan Pendidikan Biologi, 9 mahasiswa jurusan Teknologi Informatika, 3 mahasiswa jurusan
Kimia, 8 mahasiswa jurusan Pendidikan Kimia, 10 mahasiswa jurusan Pendidikan Matematika, 3 mahasiswa jurusan Matematika, 5 mahasiswa jurusan Fisika, dan 9 mahasiswa jurusan Pendidikan Fisika. Berikut diagram data semester mahasiswa atau responden :

Semester 60 tanggapan
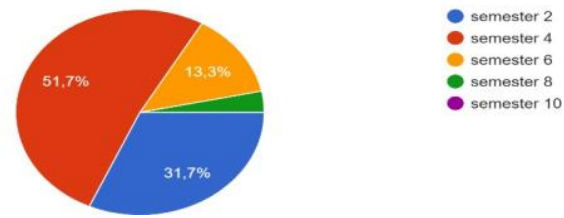

Grafik 2. Diagram Jumlah Mahasiswa

Berdasarkan Semester.

Hasil dari 60 responden yang telah mengisi survei pada point semester maka diperoleh data bahwa: 19 mahasiswa semester dua, 31 mahasiswa semester empat, 8 mahasiswa semester enam, dan 2 mahasiswa dari semester delapan.

Berikut diagram data jawaban mahasiswa atau responden terkait pertanyaan pertama:

Seberapa m Walisongo.
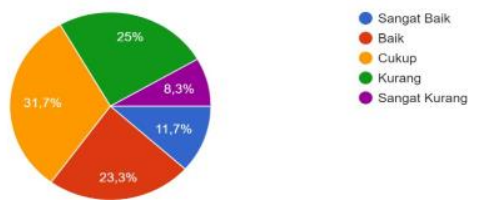

Grafik 3. Diagram Jumlah Respon Mahasiswa yang Menjawab Pertanyaan pertama.

Hasil dari 60 responden yang telah menjawab pertanyaan pertama yaitu learnbility, maka diperoleh data bahwa: 7 mahasiswa menjawab sangat baik, 14 mahasiswa menjawab baik, 19 mahasiswa menjawab cukup, 15 mahasiswa menjawab kurang, dan 5 mahasiswa menjawab sangat kurang.

Berikut diagram data jawaban mahasiswa atau responden terkait 
pertanyaan kedua :

Seberapa cep
walisongo walisongo
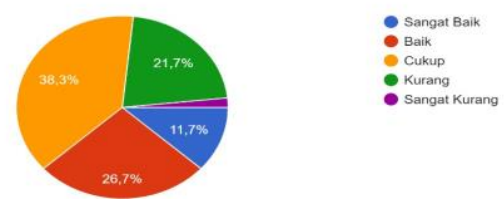

Grafik 4. Diagram Jumlah Respon Mahasiswa yang Menjawab Pertanyaan Kedua.

Hasil dari 60 responden yang telah menjawab pertanyaan kedua yaitu efficiency, maka diperoleh data bahwa: 7 mahasiswa menjawab sangat baik, 16 mahasiswa menjawab baik, 23 mahasiswa menjawab cukup, 13 mahasiswa menjawab kurang, dan 1 mahasiswa menjawab sangat kurang.

Berikut diagram data jawaban mahasiswa atau responden terkait pertanyaan Ketiga:

Seberapa ingat (terbisa) terhadap penggunaan E-learning kembali setelah lama tidak menggunakan
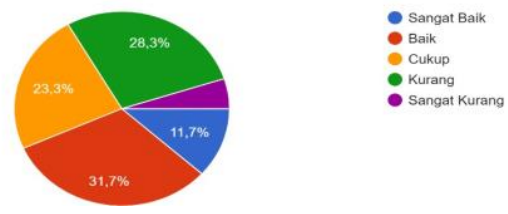

Grafik 5. Diagram Jumlah Respon Mahasiswa yang Menjawab Pertanyaan Ketiga.

Hasil dari 60 responden yang telah menjawab pertanyaan pertama yaitu memorability, maka diperoleh data bahwa: 7 mahasiswa menjawab sangat baik, 19 mahasiswa menjawab baik, 14 mahasiswa menjawab cukup, 17 mahasiswa menjawab kurang, dan 3 mahasiswa menjawab sangat kurang.

Berikut diagram data jawaban mahasiswa atau responden terkait pertanyaan keempat :
Seberapa banyak kesalahan yang diperbuat saat menggunakan E-learning walisongo(ika menurut anda tidak a
co tongagapan
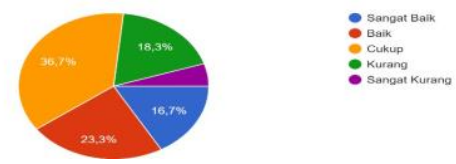

Grafik 6. Diagram Jumlah Respon Mahasiswa yang Menjawab Pertanyaan Keempat.

Hasil dari 60 responden yang telah menjawab pertanyaan pertama yaitu error, maka diperoleh data bahwa: 10 mahasiswa menjawab sangat baik, 14 mahasiswa menjawab baik, 22 mahasiswa menjawab cukup, 11 mahasiswa menjawab kurang, dan 3 mahasiswa menjawab sangat kurang.

Berikut diagram data jawaban mahasiswa atau responden terkait pertanyaan kelima:

Seberapa Puas anda dengan sistem pembelajaran E-learning
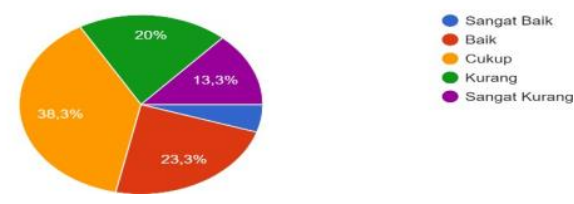

Grafik 7. Diagram Jumlah Respon Mahasiswa yang Menjawab Pertanyaan Kelima.

Hasil dari 60 responden yang telah menjawab pertanyaan pertama yaitu Satisfaction, maka diperoleh data bahwa: 3 mahasiswa menjawab sangat baik, 14 mahasiswa menjawab baik, 23 mahasiswa menjawab cukup, 12 mahasiswa menjawab kurang, dan 8 mahasiswa menjawab sangat kurang.

Dalam penelitian ini, penulis mengacu pada Skala Likert Scale, dimana masing-masing dibuat dengan menggunakan skala $1 \quad-5$ kategori jawaban, yang masing- masing jawaban diberi score (nilai) atau bobot yaitu banyaknya score antara 1 sampai 5 , dengan rincian sebagai berikut :

1. Jawaban Sangat Baik mendapat nilai 


\section{5}

2. Jawaban baik mendapat nilai 4

3. Jawaban cukup mendapat nilai 3

4. Jawaban kurang mendapat nilai 2

5. Jawaban sangat kurang mendapat nilai 1

Setelah mendapatkan data dari hasil kuisioner, kemudian data tersebut penulis olah dan analisis, sehingga didapatkan hasil sebagai berikut:

Tabel 1. Nilai Rata-rata Kriteria Nielsen

\begin{tabular}{|l|c|c|}
\hline \multicolumn{1}{|c|}{ Faktor } & $\begin{array}{c}\text { Jumlah } \\
\text { Sampel }\end{array}$ & Rata-Rata \\
\hline Keseluruhan Pengukuan & 60 & 3,12 \\
\hline Learnability & 60 & 3,05 \\
\hline Efficiency & 60 & 3,25 \\
\hline Memorability & 60 & 3,16 \\
\hline Error & 60 & 3,28 \\
\hline Satisfaction & 60 & 2,86 \\
\hline
\end{tabular}

Berdasarkan tabel diatas, dapat di lihat bahwa website e-learning walisongo memiliki tingkat usability senilai 3,12 dari skala 1-5. Ini menunjukkan website tersebut memiliki tingkat usability yang kurang baik, meskipun nilai tersebut berada diatas rata-rata, namun nilai tersebut mepet, penulis rasa masih cukup banyak kekurangan dalam sistem tersebut. Sementara masing- masing kriteria usabilitys seperti learnability $(3,05)$ atau masih dibawah dari nilai keseluruhan rata- rata, menujukkan bahwa para pengguna masih banyak yang bingung ketika menggunakan website ini pada saat pertama kali. efficiency $\quad(3,25)$, memorability $\quad(3,16)$ error $(3,28)$, ini menunjukkan bahwa sistem tersebut dapat menyelesaikan perintah dengan cepat, mudah di ingat dan sedikit error pada saat menggunakan website tersebut, satisfaction $(2,86)$ masih berada dibawah rata-rata keseluruhan, ini menandakan pengguna masih belum puas atas penggunaan website tersebut.

\section{PENUTUP}

Berdasarkan hasil survei dan analisis penerapan konsep interaksi manusia dan komputer, dalam penelitian yang dilakukan penulis memperelah beberapa hal yaitu:

1. Website E-learning yang ada di UIN Walisongo Semarang, sudah menerapkan sesuai dengan konsep interaksi manusia dan komputer meskipun belum maksimal.

2. Antarmuka pada pada sistem tersebut telah memenuhi kebutuhan pengguna khususnya mahasiswa Fakultas Saintek

3. Sistem tersebut masih telalu sulit di pelajari pada saat pertama kali menggunakan sehinga para pengguna masih banyak yang bingung.

4. Pemanfaatan E-learning walisongo secara baik telah digunakan dimana mahasiswa dapat mengetahui rekam jejak dari awal sampai lulus. Terkait semua item yang sudah ada dapat mempermudah mahasiswa untuk mengetahui rekam akademik. 


\section{REFERENCES}

ABDUL MUFTI (2015) 'RANCANGAN LAYAR SEBAGAI ALAT BANTU PENDEWASA', Faktor Exacta, 8(2), pp. 181-185. Available at: http:onesearch.id.

Alif Muwafiq Baihaqy dkk (2016) 'ANALISIS USABILITY APLIKASI E-LEARNING', Jurnal PPKM, 3, pp. 159-173. Available at: http://ojs.unsiq.ac.id.

Asnawi, N. (2018) 'Pengukuran Usability Aplikasi Google Classroom Sebagai E-learning Menggunakan USE Questionnaire (Studi Kasus: Prodi Sistem Informasi UNIPMA)', RESEARCH : Computer, Information System \& Technology Management, 1(1), p. 17. doi: 10.25273/research.v1i1.2451.

Desriyanti (2017) 'ANALISIS KONSEP INTERAKSI MANUSIA DAN KOMPUTER PADA ANTARMUKA SISTEM INFORMASI AKADEMIK UNIVERSITAS MUHAMMADIYAH PONOROGO',Jurnal

Ilmiah Multitek Indonesia, 11(1), pp. 12-23. Available at: http:journal.umpo.ac.id.

Indhira, B. (2015) 'ANALISA USABILITY PADA WEBSITE AIRLANGGA UNIVERSITY ELEARNING APPLICATIONS (Studi Deskriptif di Kalangan Mahasiswa Pengguna Website E-learning AULA)'.

Mareta Siregar (2019) 'Evaluasi Usability dan Pengalaman Pengguna Website Zenius . net Menggunakan Metode TUXEL : A Technique for User Experience Evaluation in eLearning', Jurnal Pengembangan Teknologi Informasi dan Ilmu Komputer, 3(5), pp. 5058-5067. Available at: http://j-ptiik.ub.ac.id.

Muzid, Syafiul dan Munir, Mishbahul. 2005. Persepsi Mahasiswa dalam Penerapan E-learning sebagai Aplikasi Peningkatan Kualitas Pendidikan (Studi Kasus pada Universitas Islam Indonesia). Seminar Nasional Aplikasi Teknologi Informasi. Yogyakarta

Pambudi, R. dkk. (2018) 'Analisis dan Pengukuran Tingkat Ketergunaan ( Usability ) Penggunaan Website E-learning di Jurusan Ilmu Komputer Universitas Negeri Semarang', Techno.COM. Available at: http://publikasi.dinus.ac.id.

Prabantoro, Gatot dan Hidayat, Agus. 2005. Pemanfaatan Fasilitas Gratis di Dunia Maya untuk Pengembangan Media E-learning Murah (Studi Empiris Pengembangan Situs Kelas Sistem Informasi Manajemen). Seminar Nasional Aplikasi Teknologi Informasi. Yogyakarta

Rahadian, D., Rahayu, G. and Oktavia, R. R. (2019) 'Teknologi Pendidikan: Kajian Aplikasi Ruangguru Berdasarkan Prinsip dan Paradigma Interaksi Manusia dan Komputer', Jurnal Petik, 5(1), pp. 11-24. doi: 10.31980/jpetik.v5i1.489.

Siahaan, Sudirman. 2001. E-learning (Pembelajaran Elektronik) sebagai Salah Satu Alternatif Kegiatan Pembelajaran.

Suyanto, Asep Herman. 2010. Pengenalan E-learning. Diambil dari http://www.jurnalkomputer.com

Thoyyibah T. (2018) 'Universitas Pamulang didirikan pada', JURNAL TEKNIK INFORMATIKA, 11(2), pp. 139-149. Available at: http://jurnal.teknikunkris.ac.id. 
Wulandari, I. R. (2018) 'PENGUKURAN USER EXPERIENCE PADA E-LEARNING DI LINGKUNGAN UNIVERSITAS MENGGUNAKAN USER EXPERIENCE QUESTIONNARE ( UEQ )', jurnal mantik penusa, 2(2), pp. 146-151. Available at: http://ejurnal.pelitanusantara.ac.id.

Watts, Ronald. 1999. Re-engineering the learning process. Diambil dari http://www.ukoln.ac.uk/services/papers/bl/blri078/content/repor 23.htm 